\title{
A Paradox Within The Time Value Of Money: A Critical Thinking Exercise For Finance Students
}

Charles J. Delaney, Baylor University, USA

Steven P. Rich, Baylor University, USA

John T. Rose, Baylor University, USA

\begin{abstract}
This study presents a paradox within the time value of money (TVM), namely, that the interest-principal sequence embedded in the payment stream of an amortized loan is exactly the opposite of the interest-principal sequence implicit in the present value of a matching annuity. We examine this inverse sequence, both mathematically and intuitively, and argue that it provides an excellent exercise for finance students to explore, both to enhance their critical thinking skills as well as to strengthen their understanding of TVM concepts. Additionally, such an exercise will involve them actively in the learning process, as mandated by AACSB International's Eligibility Procedures and Standards for Business Accreditation.
\end{abstract}

Keywords: Time Value Of Money; Interest-Principal Sequence; Amortization Schedule; Annuity Present Value

\section{INTRODUCTION}

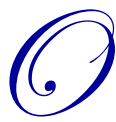

ver the last several decades the technology for teaching finance-specifically, the time value of money (TVM) - has advanced from published tables to hand-held financial calculators, spreadsheet (Excel) software, and now apps for smart phones. While this evolution has no doubt enhanced students' ability to address more complex TVM problems, there is a risk, namely, that students will lose an appreciation of the underlying concepts (theory) supporting the calculations.

This study presents a paradox within the time value of money for finance students to explore, both to enhance their critical thinking skills and to strengthen their understanding of TVM concepts. Such an exercise will also involve them actively in the learning process, as mandated by AACSB International's Eligibility Procedures and Standards for Business Accreditation. The paradox is the surprising result that the interest-principal sequence embedded in the payment stream of an amortized loan is exactly the opposite of the interest-principal sequence implicit in the present value of a matching annuity. This finding is presented in the next section, followed by discussions of the mathematics and intuition of the inverse relationship in Sections III and IV, respectively. For students the exercise would be to study Sections III and IV or, for more advanced students, to ask them to develop independently the mathematics and intuition of the inverse sequence. Section V is a summary and conclusion. Interestingly, no finance (or real estate) textbook of which we are aware recognizes this paradox. ${ }^{1}$

\section{THE PARADOX EXPLAINED}

Suppose a lender makes a 5-year, $6 \%$ amortized loan of $\$ 4,212.36$ with annual payments. As any beginning finance or real estate student knows, using the present value of an ordinary annuity (PVAN) formula where PVAN = $\$ 4,212.36$, the student can calculate the annual payment as $\$ 1,000$. Armed with this information the student can then construct an amortization schedule, as shown in Table 1 below, to give the combination of interest and

\footnotetext{
${ }^{1}$ Introductory finance textbooks, as well as real estate principles texts, typically discuss the present value of an annuity as a segue to addressing amortized loans. However, none of the sixteen texts reviewed for this study note the inverse interest-principal sequence between the amortization schedule and the present values of matching annuity payments. See a listing of the books reviewed in the References.
} 
principal paid by the borrower (and received by the lender) in each successive loan payment. The result is a stream of constant annual payments to the lender characterized by a sequence of decreasing interest and increasing principal components such that the lender receives the contract interest rate each year on the remaining (beginningof-year) loan balance.

Table 1. Amortization Schedule

\begin{tabular}{r|r|c|r|r|r}
\hline \multicolumn{1}{c|}{ Year } & Begin & Payment & Interest & Principal & End \\
\hline 1 & $4,212.36$ & $1,000.00$ & 252.74 & 747.26 & $3,465.11$ \\
\hline 2 & $3,465.11$ & $1,000.00$ & 207.91 & 792.09 & $2,673.01$ \\
\hline 3 & $2,673.01$ & $1,000.00$ & 160.38 & 839.62 & $1,833.39$ \\
\hline 4 & $1,833.39$ & $1,000.00$ & 110.00 & 890.00 & 943.40 \\
\hline 5 & 943.40 & $1,000.00$ & 56.60 & 943.40 & 0.00 \\
\hline
\end{tabular}

Now suppose that the lender immediately sells the loan to another investor, either as a stand-alone investment or as part of a securitized packet of loans. At what price should the loan trade? Presumably, the loan should sell at the annuitized (present) value of the 5-year stream of expected annual $\$ 1,000$ payments discounted at the $6 \%$ contract interest rate, assuming the appropriate risk-adjusted rate has not changed between the time of loan origination and sale. The stream of present values is shown below in Table 2 and summed to give the annuitized (present) value of $\$ 4,212.36$. But note that because present values essentially extract the interest component inherent in future payments, the result is an implicit sequence of increasing interest and decreasing principal components in the valuation calculated by the investor. Moreover, the increasing interest/decreasing principal sequence in the present values of the annuity payments is exactly the opposite of the amortization sequence of decreasing interest/increasing principal (shown in Table 1) that would have been received by the original lender and would now be received by the purchasing investor. ${ }^{2}$

Table 2. Annuity Valuation

\begin{tabular}{l|c|c|c}
\hline Year & Present Value & Interest & Payment \\
\hline 1 & 943.40 & 56.60 & 1,000 \\
\hline 2 & 890.00 & 110.00 & 1,000 \\
\hline 3 & 839.62 & 160.38 & 1,000 \\
\hline 4 & 792.09 & 207.91 & 1,000 \\
\hline 5 & 747.26 & 252.74 & 1,000 \\
\hline Total & $4,212.36$ & 787.64 & 5,000 \\
\hline
\end{tabular}

But what accounts for the inverse interest-principal sequence between the amortization schedule and the present values of matching annuity payments, given that the constant payment stream within the amortization schedule is itself constructed from the PVAN formula? We explore this paradox in the remainder of this note, beginning in the next section with the mathematics of the inverse sequence. Section III then presents an intuitive presentation of the different sequences by noting the dual ways that one can view the present value of an annuity. Finally, the last section concludes by suggesting the benefits to finance students from exploring this inverse interest-principal sequence.

\section{THE MATHEMATICS OF THE INVERSE INTEREST-PRINCIPAL SEQUENCE}

To understand the inverse interest-principal sequence, consider a fully amortized loan with $N$ annual payments of $C$ and a contract interest rate of $r$. Consider also an annuity of $N$ annual payments of $C$ earning an interest rate of $r$. To see why the interest in the first payment of the $N$-period loan $(\$ 252.74$ in the 5-year loan shown in Table 1) must equal the interest implicitly embedded in the $N^{\text {th }}$ payment of the annuity $\left(\$ 252.74\right.$ in the $5^{\text {th }}$ year of the annuity shown in Table 2), we need to define the interest in the first payment of the $N$-period loan and the interest implicitly embedded in the $N^{\text {th }}$ payment of the annuity.

\footnotetext{
${ }^{2}$ It should be emphasized that the numbers in Tables 1 and 2 are not calculated the same way. For example, the interest of $\$ 252.74$ in Year 1 of Table A equals $\$ 4,212.36 \times .06$, whereas the interest of $\$ 252.74$ in Year 5 of Table B equals $\$ 1,000-\left[\$ 1,000 /(1.06)^{5}\right]$.
} 
Let $I N T L_{l}$ equal the interest paid during the first year of an $N$-year amortized loan with an interest rate of $r$ and annual constant payments of $C$ at the end of each year. $I N T L_{1}$ thus equals the interest rate multiplied by the amount borrowed which, in turn, can be written as the interest rate multiplied by the present value of the stream of $N$ constant payments of $C$ discounted at rate $r$, as follows:

$$
I N T L_{1}=r \times\left(\frac{C}{r}\left(1-\frac{1}{(1+r)^{N}}\right)\right)=C-\frac{C}{(1+r)^{N}}
$$

Next, let $I N T A_{N}$ equal the interest implicitly embedded in the $N^{\text {th }}$ payment of an $N$-year ordinary annuity promising annual payments of $C$ with an interest rate of $r$. INTA $A_{N}$ thus equals the $N^{\text {th }}$ payment of $C$ less the present value of $C$ discounted at rate $r$ for $N$ years, as follows:

$$
\operatorname{INT} A_{N}=C-\frac{C}{(1+r)^{N}}
$$

Thus, $I N T L_{1}$ must equal $I N T A_{N}$ for any $C, r$, and $N$. Moreover, the equality holds in general for the interest paid during any $k^{\text {th }}$ year of the amortized loan and the interest implicitly embedded in the $[N-(k-1)]^{\text {th }}$ payment of the annuity.

\section{DUAL WAYS TO VIEW THE PRESENT VALUE OF AN ANNUITY}

This section explores the intuition of the inverse interest-principal sequence as shown in Tables 1 and 2 by recognizing the dual ways that one may view the present value of an annuity (PVAN). First, from a single investment perspective one may think of the PVAN $(\$ 4,212.36)$ as a lump sum invested at $6 \%$ for the next 5 years. Such an investment would allow the investor to receive a constant payment of $\$ 1,000$ at the end of each year, always earning $6 \%$ on the remaining balance of the $\$ 4,212.36$ investment, and have nothing left in the investment account at the end of year 5. From this perspective the first $\$ 1,000$ payment represents interest of $(\$ 4,212.37 \times .06)=\$ 252.74$ plus principal of $(\$ 1,000-\$ 252.74)=\$ 747.26$, which leaves a remaining investment balance of $\$ 4,212.37$ - $\$ 747.26$ $=\$ 3,465.11$ at the end of Year 1 . The second $\$ 1,000$ payment then represents interest of $(\$ 3,465.11 \times .06)=$ $\$ 207.91$ plus principal of $(\$ 1,000-\$ 207.91)=\$ 792.09$, which leaves a remaining investment balance of $\$ 3,465.11$ $\$ 792.09=\$ 2,673.02$ at the end of Year 2. Continuing the sequence of calculations results in a decreasing interest/increasing principal mix across the sequence of payments, thereby generating the amortization schedule shown previously in Table 1.

Alternatively, the PVAN $(\$ 4,212.36)$ may be viewed as the sum of 5 investments made for a sequence of $1-5$ years each at $6 \%$. Such a series of investments would allow the investor to receive a constant payment of $\$ 1,000$ at the end of each year, thereby earning a compounded $6 \%$ on each sequential investment component of the $\$ 4,212.36$, and have nothing left in the investment account at the end of Year 5. From this perspective the first $\$ 1,000$ payment represents $\$ 943.40 \times(1.06)^{1}=943.40$ (principal) $+\$ 56.60$ (interest); the second $\$ 1,000$ payment represents $\$ 890.00$ $\mathrm{x}(1.06)^{2}=\$ 890.00$ (principal) $+\$ 110.00$ (interest); and so forth. The result is an increasing interest/decreasing principal mix across the sequence of payments, thereby generating the annuity valuation shown earlier in Table 2 .

\section{SUMMARY AND CONCLUSION}

Introductory finance textbooks, as well as real estate principles texts, routinely address the present value of an annuity (PVAN) calculation and show that the PVAN formula can be used to calculate the constant payment for an amortized loan. However, we know of no textbook that recognizes that the interest-principal sequence embedded in the payment stream of an amortized loan is exactly the opposite of the interest-principal sequence implicit in the payment stream of a matching annuity. This study examines this paradox, including both its mathematics and intuition, and suggests using it as an issue for finance students to examine in order to strengthen their understanding of the time value of money as it plays itself out in annuity and amortization calculations. Additionally, it provides an excellent exercise to enhance finance students' critical thinking skills as well as to involve them actively in the learning process, as mandated by AACSB International's Eligibility Procedures and Standards for Business Accreditation. 


\section{AUTHOR BIOGRAPHIES}

Dr. Delaney has taught a variety of real estate courses at Baylor since 1988. He has published over 40 articles in leading real estate journals. In addition, Dr. Delaney was Visiting Research Scholar at Swinburne University in Melbourne, Australia from 1992 to 1994 and has provided consulting services to Goldman Sachs and served as an expert witness in litigation. A graduate of the University of Rhode Island, Delaney holds M.A. and Ph.D. degrees from the University of Florida in Gainesville. Email: charles_delaney@baylor.edu

Dr. Rich has primarily taught corporate finance at Baylor University since 1988. While at Baylor he has received numerous teaching awards from student organizations as well as from the University. Dr. Rich has also published finance and real estate articles in academic, professional, and pedagogical journals. A graduate of Baylor University, Rich earned a Ph.D. in finance from Indiana University in 1989. Email: jt_rose@baylor.edu

Prior to coming to Baylor in 1984 Dr. Rose worked for twelve years as an economist at the Federal Reserve Board, Washington, D.C. While at Baylor he has taught principles of financial management and commercial bank management, and he served as Chair of the Department of Finance, Insurance, and Real Estate from 1996-2006. Dr. Rose has published numerous articles on banking and finance in academic and professional journals, most recently in the field of finance pedagogy. A graduate of Texas A\&M University, Rose holds M.A. and Ph.D. degrees in economics from Washington University in St. Louis. E-mail: jt_rose@baylor.edu (Contact Author)

\section{REFERENCES}

Berk, J., DeMarzo, P., \& Harford, J. (2009). Fundamentals of Corporate Finance, Boston: Pearson Education, Inc.

Block, S. B., \& Hirt, G. A. (2008). Foundations of Financial Management, $2^{\text {th }}$ edition, New York: McGraw-Hill/Irwin.

Brigham, E. F., \& Houston, J. F. (2015). Fundamentals of Financial Management, concise $8^{\text {th }}$ edition, Mason, OH: SouthWestern, Cengage Learning.

Brooks, R. M. (2013). Financial Management: Core Concepts, $2^{\text {nd }}$ edition, Boston: Pearson Education, Inc.

Floyd, C. F., \& Allen, M. T. (2014). Real Estate Principles, $11^{\text {th }}$ edition, LaCrosse, WI: Dearborn Real Estate Education.

Gallagher, T. J. (2012). Financial Management: Principles and Practice, $6^{\text {th }}$ edition, Minneapolis: Freeload Press.

Gitman, L. J. (2009). Principles of Managerial Finance, $12^{\text {th }}$ edition, Boston: Pearson Education, Inc..

Keown, A. J., Martin, J.D., Petty, J. W., \& Scott, Jr., D. F. (2014). Foundations of Finance: The Logic and Practice of Financial Management, $8^{\text {th }}$ edition, Boston: Pearson Education, Inc.

Lasher, W. R. (2014). Practical Financial Management, $7^{\text {th }}$ edition, Mason, OH: South-Western, Cengage Learning.

Ling, D. C., \& Archer, W. R. (2009).Real Estate Principles: A Value Approach, $3^{\text {rd }}$ edition, Chicago: McGraw-Hill/Irwin.

Megginson, W. L., \& Smart, S. B. (2009). Introduction to Corporate Finance, $2^{\text {nd }}$ edition, Mason, OH: South-Western, Cengage Learning.

Melicher, R. W., \& Norton, E. A. (2014). Introduction to Finance: Markets, Investments, and Financial Management, 15 ${ }^{\text {th }}$ edition, Hoboken, NJ: John Wiley \& Sons, Inc..

Moyer, R. C., McGuigan, J. R., \& Kretlow, W. J. (2015). Contemporary Financial Management, 13 ${ }^{\text {th }}$ edition, Stamford: CT: Cengage Learning.

Parrino, R.D., Kidwell, S., \& Bates, T. W. (2012). Fundamentals of Corporate Finance, $2^{\text {nd }}$ edition, Hoboken, NJ: John Wiley \& Sons, Inc.

Ross, S. A., Westerfield, R. W., \& Jordan B. D. (2014). Essentials of Corporate Finance, $8^{\text {th }}$ edition, New York: McGrawHill/Irwin.

Shilling, J. D. (2002). Real Estate, $13^{\text {th }}$ edition, Cincinnati: South-Western. 